\title{
Accurate validation of ultrasound imaging of prostate cancer: a review of challenges in registration of imaging and histopathology
}

\author{
Rogier R. Wildeboer ${ }^{1}$ (1) $\cdot$ Ruud J.G. van Sloun ${ }^{1} \cdot$ Arnoud W. Postema $^{2} \cdot$ Christophe K. Mannaerts $^{2} \cdot$ Maudy Gayet $^{3}$. \\ Harrie P. Beerlage ${ }^{3} \cdot$ Hessel Wijkstra $^{1,2} \cdot$ Massimo Mischi $^{1}$
}

Received: 9 April 2018 / Accepted: 11 July 2018 / Published online: 30 July 2018

(c) The Author(s) 2018

\begin{abstract}
As the development of modalities for prostate cancer (PCa) imaging advances, the challenge of accurate registration between images and histopathologic ground truth becomes more pressing. Localization of PCa, rather than detection, requires a pixel-to-pixel validation of imaging based on histopathology after radical prostatectomy. Such a registration procedure is challenging for ultrasound modalities; not only the deformations of the prostate after resection have to be taken into account, but also the deformation due to the employed transrectal probe and the mismatch in orientation between imaging planes and pathology slices. In this work, we review the latest techniques to facilitate accurate validation of PCa localization in ultrasound imaging studies and extrapolate a general strategy for implementation of a registration procedure.
\end{abstract}

Keywords Prostate cancer $\cdot$ Diagnostic imaging $\cdot$ Validation studies as topic $\cdot$ Histology $\cdot$ Review

\section{SOMMARIO}

Con lo sviluppo di nuove tecnologie di imaging per il cancro alla prostata, è diventata più pressante l'esigenza di una accurata registrazione e confronto tra le immagini e i reperti istopatologici. La localizzazione del tumore prostatico, oltre che il suo riconoscimento, richiede una validazione "pixel-topixel" dell'imaging basata sulla sua istopatologia ottenuta con la prostatectomia radicale. La tecnica di registrazione è cruciale per la metodica ecografica; devono essere tenute in conto non solo le deformazioni della prostata dopo resezione, ma anche la deformazione dovuta alla sonda transrettale impiegata e la possibile non corrispondenza tra i piani di orientamento impiegati nella formazione delle immagini e le sezioni istologiche. In questo lavoro gli Autori fanno una revisione delle recenti tecniche che facilitano la localizzazione del cancro della prostata in diagnostica ecografica ed estrapolano possibili strategie generali per implementare le procedure di registrazione degli esami.

\section{List of abbreviations \\ 2D Two-dimensional \\ 3D Three-dimensional \\ AT Affine transformation \\ BSp Basis-spline}

Rogier R. Wildeboer

r.r.wildeboer@tue.nl

1 Laboratory of Biomedical Diagnostics, Department of Electrical Engineering, Eindhoven University of Technology, De Rondom 70, 5612 AP Eindhoven, The Netherlands

2 Department of Urology, Academic Medical Center University Hospital, Meibergdreef 9, 1105 AZ Amsterdam, The Netherlands

3 Department of Urology, Jeroen Bosch Hospital, Henri Dunantstraat 1, 5223 GZ 'S-Hertogenbosch, The Netherlands
CT Computed tomography

PCa Prostate cancer

PET Positron emission tomography

RBF Radial-basis function

RP Radical prostatectomy

TPS Thin-plate spline

TRE Target registration error

MRI Magnetic resonance imaging

US Ultrasound

\section{Introduction}

Prostate cancer (PCa) imaging is a very active field in medical science. Even though PCa exhibits the highest cancer incidence among the American male population [1], reliable imaging methods are not yet available. As a consequence, 
systematic 10-12-core needle-biopsy still is the guidelinerecommended diagnostic strategy [2], a procedure that is known to lead to under diagnosis, overtreatment and complications [3, 4]. Research groups around the world are, therefore, investing in the development of imaging tools that might facilitate targeted biopsy and ultimately replace the biopsy procedure altogether. In addition, focal therapies are emerging to avoid the severe side effects associated with radical treatment of $\mathrm{PCa}$, increasing the need for reliable imaging for treatment planning, monitoring and follow-up [5].

The development of new imaging technologies requires rigorous validation with the histopathological ground truth. Although histopathology of the excised prostate specimen after radical prostatectomy (RP) is considered to be preferred to validate PCa localization [6, 7], most investigators have been using transperineal or transrectal biopsies as reference standard (see, e.g. meta-analyses for multiparametric Magnetic Resonance Imaging (mpMRI) [6, 7]; ultrasound (US) modalities [8, 9]; and Positron Emission Tomography (PET)/Computed Tomography (CT), [10]). When RP histopathology is available, validation is generally based on cognitive matching between image and histopathology. Although seemingly straightforward, this procedure can be difficult, is prone to errors, and requires many (invalid) underlying assumptions. Researchers are, therefore, forced to perform the validation in regions, quadrants, zones or the prostate as a whole [6-10]. For targeted biopsy and focal therapy, however, we should aim for tumour localization at a higher resolution.

Matching of images and histopathology is a challenge; the prostate deforms considerably after excision and pathological preparation and these substantial differences between in vivo and ex vivo shape must be compensated. In the past decades, many registration methods have been developed to map the ex vivo findings onto the in vivo images. For MRI, $\mathrm{CT}$ and PET, slice selection algorithms have been implemented to find the exact lesion locations in the image [11, 12]. In this respect, ultrasonic modalities are often overlooked, since their typical two-dimensional imaging planes are very differently oriented than the histopathology slices $[13,14]$. Moreover, the manual pressure of the transrectal probe adds to the deformation between in vivo and ex vivo [13]. In this review, we survey the spectrum of available techniques and other important considerations for an accurate validation of ultrasonic techniques for prostate cancer imaging.

\section{General workflow}

In general, pixel-to-pixel validation strategies require a standardized histopathology protocol (in which the histopathological data are assembled into a model), a registration procedure (in which deformations are compensated for) and a correlation step (in which the pathology-proven $\mathrm{PCa}$ lesions are superimposed onto the images). We review these steps sequentially.

\section{Step 1A: histopathological modelling}

The standard pathology protocol comprises RP specimen fixation, sectioning in 2-4-mm thick slices, staining of frontfaces and histopathologic examination of whole-mount or smaller sections $[15,16]$. As previously mentioned, twodimensional (2D) transrectal US imaging planes often have a very different orientation than the RP slices. An imaging plane can, therefore, only be accurately matched to histopathologic data by combining the information from all slices it crosses. Three-dimensional reconstruction and adequate interpolation of histopathology are, therefore, of vital importance [11, 17-19]. These models can also be readily used for the validation of three-dimensional (3D) US imaging solutions for B-mode, elastography and contrast-enhanced ultrasonography [20]. Paradoxically, validation of 3D imaging modalities is less dependent on a proper 3D histology model as their imaging is not bound two a particular 2D plane (i.e. one can select the voxels that correspond to the histological slice).

To construct a suitable histopathological model, one hugely relies on assumptions concerning slice location, orientation and deformations during the pathological work flow [21]. However, it has been reported that almost nine tenth of European pathologists section the prostate without using a special cutting device [22], which might lead to histopathologic slices not being parallel or of equal thickness [23]. In recent years, many groups developed slicing devices to standardize the sectioning process and minimize inaccuracies [24]. Still, it was quantified that microtome cutting exhibits standard deviations of $0.2-0.5 \mathrm{~mm}$ in $\sim 4-\mathrm{mm}$ thick slices and $0.9^{\circ}-1.1^{\circ}$ in inter-slice front-face orientation [21, $25,26]$.

The conversion to three dimensions requires spatial alignment of the histopathologically annotated slices. Although manual alignment is most common [11], there are strategies involving the use of anatomical landmarks (e.g. [27]), blockface photographs taken during the sectioning process (e.g. $[12,21])$ or mutual information-based intensity matching (e.g. [28]). As natural features and other (anatomical) information do not usually persist over multiple slicing distances, similarity-based alignment becomes increasingly difficult 
Table 1 3D modelling of histopathology and imaging

\begin{tabular}{|c|c|c|c|c|c|}
\hline \multicolumn{2}{|c|}{ Source(s) } & \multirow{2}{*}{$\frac{\text { Modality }}{\text { Histology }}$} & \multirow{2}{*}{$\begin{array}{l}\text { Method } \\
\text { 3D stacking, interpolation over inter-slice } \\
\text { thickness }\end{array}$} & \multirow{2}{*}{$\begin{array}{l}\text { Validation method } \\
-\end{array}$} & \multirow[t]{2}{*}{ Performance } \\
\hline [31] & Malone, 2014 & & & & \\
\hline [33] & Wildeboer, 2017 & Histology & Radial-basis functions & 90th percentile surface deviation simulation & $1.5 \mathrm{~mm}$ \\
\hline [29] & Taylor, 2004 & Histology & $\begin{array}{l}\text { Spline interpolation of distance field [72] } \\
\text { ex vivo US }\end{array}$ & Specimen volume accuracy & $92 \% \pm 3 \%$ \\
\hline [73] & Hughes, 2012 & Histology & Stacking based on fiducial markers & Average deviation of ejactory ducts & $1.5 \mathrm{~mm}$ \\
\hline [74] & Werahera, 1995 & Histology & $\begin{array}{l}\text { Linear inter-slice interpolation and extrapo- } \\
\text { lation }\end{array}$ & Specimen volume accuracy & $\sim 4.5 \%$ \\
\hline [75] & Xuan, 1997 & Histology & Elastic contour interpolation & - & - \\
\hline [75] & Xuan, 1997 & Histology & Surface spine model & - & - \\
\hline [76] & Tutar, 2004 & Ultrasound & Fourier-description deformable models & - & - \\
\hline [14] & Cool, 2006 & Ultrasound & Radial-basis functions & Mean surface deviation simulation & $1.34 \pm 0.20 \mathrm{~mm}$ \\
\hline [77] & Hibbard, 2012 & Ultrasound & $\begin{array}{l}\text { Shape-optimal RBFs implicit surface } \\
\text { reconstruction }\end{array}$ & Mean surface deviation expert & $<0.5 \mathrm{~mm}$ \\
\hline
\end{tabular}

$R B F$ radial-basis functions
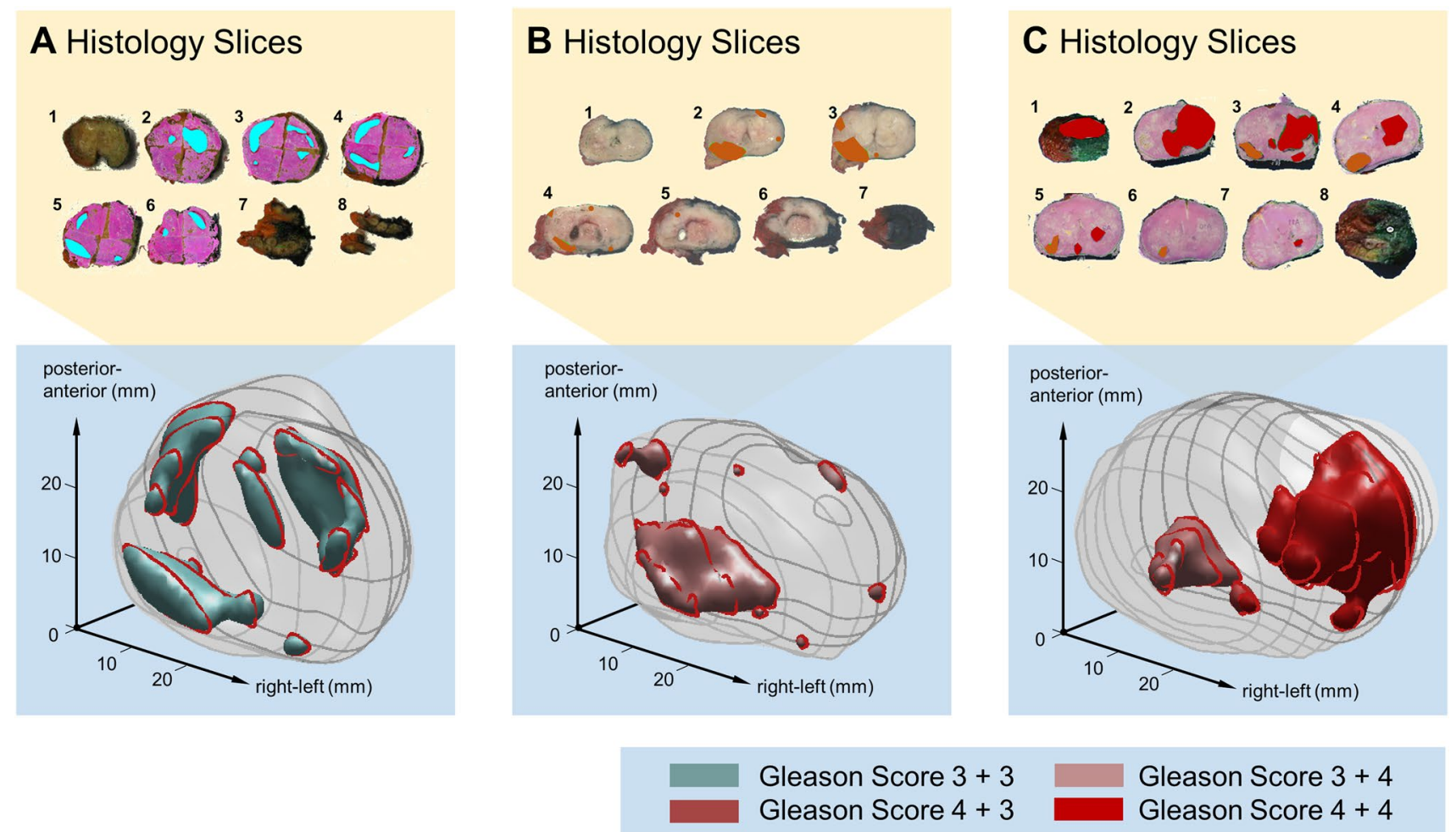

Fig. 1 Three examples of 3D histopathology reconstructions from tumour-delineated macro-photos of the sliced radical prostatectomy specimen a-c. Volumetric lesions are colour-coded to depict their Gleason Score

when using larger slice thicknesses [27]. Some authors introduce external fiducial markers to guide the alignment [27, 29, 30]. Naturally, lower reconstruction errors associated with more sophisticated techniques come at the price of the labour involved.

There are many algorithms available to build volumetric structures from stacked 2D data. For PCa lesions, most 
reported are simply stacking the slices [12] and extrapolating the histopathologic data over the entire slice thickness [31, 32]. More sophisticated algorithms use radial-basis functions [33] or spline functions [29] to smoothly interpolate the histopathologic data between the slices. A comprehensive overview of techniques is listed in Table 1. Obviously, the accuracy of these methods relies to a great extent on the precision of slicing and alignment. In previously published work, we found that a standard clinical workflow would lead to a 1.5 -mm error margin in tumour boundary location [33]. As an example, Fig. 1 features an illustration of the 3D models generated by this technique.

Some studies make use of ex vivo imaging before slicing [12, 26, 34-37]. As an intermediate step, the histopathological data are mapped onto the deformed, ex vivo 3D model of the prostate prior to the registration to the in vivo shape. A comparison of registration with and without ex vivo MRI, however, did not show significant improvement [38]. This suggests that in vivo to ex vivo mapping is the crucial transformation. Moreover, even when ex vivo (US) scans are used for the histopathology reconstruction, this method would still require interpolation of the tumour delineations into tumour volumes.

\section{Step 1B: three-dimensional modelling of imaging}

As we are interested in matching the in vivo and ex vivo prostate, a 3D model of the in vivo shape is also required. When 3D imaging is not available, such a model can be reconstructed from a 2D sweep (e.g. [13]) as shown in Fig. 2. The 2D images will have to be segmented and connected, for example using algorithms similar to those used for tumour interpolation (see Table 1). As described in Step 3 , it is important to retrieve the location of the imaging plane of interest in this 3D model afterwards.

\section{Step 2: registration}

Unfortunately, it is not possible to directly match the in vivo prostate to the reconstructed RP specimen, even when the ex vivo shape is perfectly restored. Mainly the loss of vascular pressure and the absence of the connective tissue encapsulation after removal from the body cause the prostate to deform after resection. Orzcyk et al. have shown that the prostate shrinks unevenly; on average, the prostate is $2.9 \%$ smaller in the base-apical direction, whereas it shrinks by 9.7\% in the anterior-posterior direction [39]. The pathological preparation of the ex vivo specimen also has an effect (especially the formalin fixation [40] and cutting procedure [24]), whereas the in vivo shape might already have been changed by a filled bladder pressing onto the gland. Moreover, ultrasonic modalities alter the in vivo shape considerably by employing a transrectal probe. On top of that, there are indications of inhomogeneous deformation within the prostate due to differences in tissue elasticity between zones and between anatomical or pathological features [41, 42].

Registration algorithms are designed to digitally translate the deformed prostate back to its original form, ranging from rigid (i.e. only translation and rotation) to fully elastic methods. Many prostate-applicable algorithms have been developed for MRI, but these can often be readily applied to US. Techniques that only work in 2D, because they make use of prior MRI-slice to histopathology-slice matching [18, 26, 34, 43-47], will have to be expanded to 3D. Unfortunately,

\section{A Ultrasound Sweep}

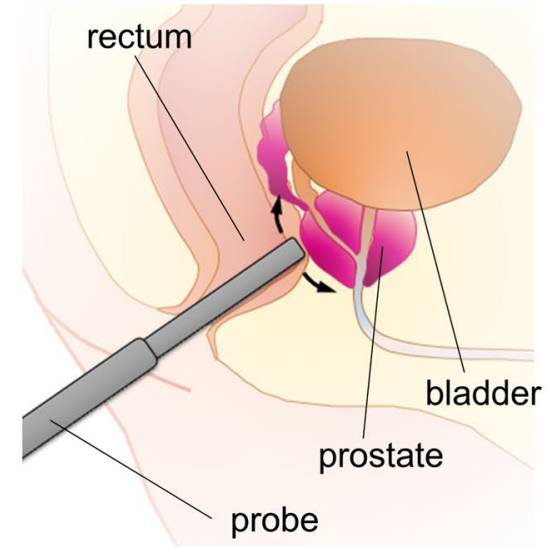

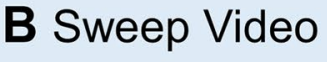

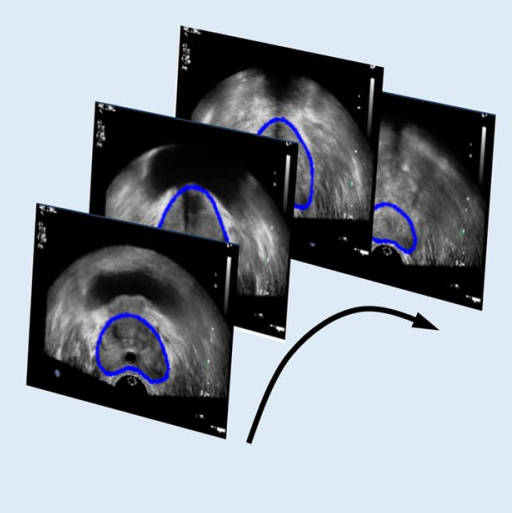

C 3D in-vivo Model

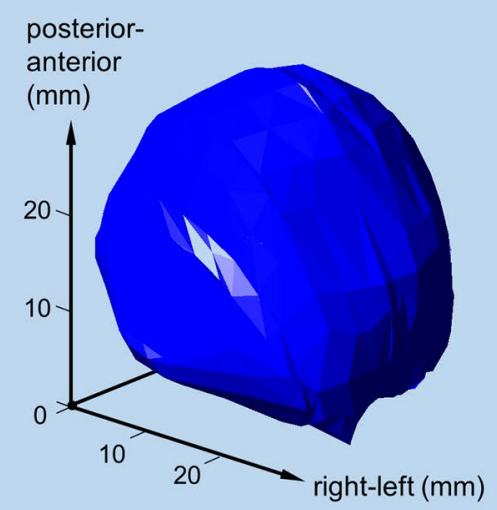

Fig. 2 Example of in vivo 3D reconstruction of the prostate based on a 2D US sweep: a schematic of the sweep procedure, $\mathbf{b}$ representation of manually segmented prostate in the ultrasound sweep video, and $\mathbf{c}$ resulting $3 \mathrm{D}$ reconstruction 
some of these methods, especially those using similarity measures, would then be seriously hampered by the low resolution in the longitudinal direction, requiring a slicing distance below the $\mathrm{mm}$ range.

It is important to note that registration techniques need guidance, that is, they require spatial correspondence information from both modalities to estimate the mapping from one to another. Conventionally, this is either intensity based or landmark based. For the latter approach, the prostatic capsule or (anatomical) landmarks are manually or automatically pinpointed in histopathology as well as imaging. The intensity-based approach does not need specific landmark pairs, but uses full-image similarity features such as correlation or mutual information between histopathology and imaging to guide the registration. As a next step, a warping algorithm interpolates the voxel-to-voxel displacement over the entire image. For this purpose, researchers have exploited everything from affine transformations (AT) (e.g. rotation, translation, scaling) up to elastic methods, based on basis-splines (BSp) [48] or thin-plate splines (TPS) [49].

A special case of registration is the use of image-based moulds [50-54]. This procedure requires a three-dimensional in vivo scan to fabricate a tailor-made mould to force the specimen into its in vivo shape during the sectioning process. Moulds can also be used to simulate a transrectal probe pressing against the specimen; however, for MRI, an endorectal-coil mimicking mould did not significantly improve the registration performance [55]. Obviously, moulding cannot take into account deformations within the prostate and cannot compensate for inhomogeneous shrinkage. The position and orientation of the prostate slices, on the other hand, are well controlled and easily recoverable.

In Table 2, a selection of registration methods applied in the prostate is listed. It is worth noting that the labour required substantially differs between registration procedures. Whereas semi-automated algorithms are easily manageable, protocols requiring manual delineation or ex vivo scans and fiducial marker placement are increasingly laborious. We also note that the performance of the various registration procedures is not verified in the same manner, making it difficult to compare the strategies; most articles quantify the error by the target registration error (TRE), but others mention the volumetric overlap or the result of visual inspection. Typically, only a relatively low number of prostatic specimens is used for the validation.

\section{Step 3: correlation}

The final step is the transition from the registered threedimensional models to the actual images. If the histopathology is directly registered to the ultrasonic modality under investigation, histopathologic voxels are easily mapped to imaging voxels or pixels (in which case, a model cross-section needs to be computed). For the evaluation of elastography or contrast-enhanced images and videos, the registration might have been performed to a three-dimensional or three-dimensionalized B-mode ultrasound first (as mentioned in Step 1B). Another registration step between B-mode and the final modality is then needed. Intra-modality registration could be performed along the same lines as in Step 2, or using fusion techniques as those mentioned in the Discussion [56].

\section{Discussion}

Ultrasound imaging of the prostate is still rapidly advancing and especially promising modalities such as power Doppler [57], elastography [58], and contrast-enhanced ultrasound [59] have been extensively studied in recent years. Due to prostate deformation after excision, the effect of the transrectal probe, and the imaging planes not being parallel, histopathological validation using RP specimens is challenging.

Based on our review of the literature, we have found that full histopathology-prostate registration is essentially a three-step process combining reconstruction, registration and correlation. For illustrative purposes, Fig. 3 depicts a possible procedure, matching contrast-enhanced ultrasound videos to histopathology. As no 3D imaging is available in this example, both a 3D histopathologic model [33] and a $3 \mathrm{D}$ in vivo model based on a B-mode US sweep are built. In this case, the models are subsequently registered using the method presented by Schalk et al. [13]. Now, by cognitively locating each imaging plane of the contrast recording in the B-mode sweep, histopathological cross-sections matching the contrast-ultrasound images can be computed. In a similar way, other reconstruction (Step 1) and registration (Step 2) techniques can be implemented and combined. We have found that most algorithms achieve an accuracy in the millimetre range. By employing an error margin between benign and malignant regions in the validation, one can take this into account.

Nonetheless, the question remains how small such a margin should be. Most papers stress that clinically significant tumours have radii exceeding $5 \mathrm{~mm}$ (having a cutoff volume of $0.5 \mathrm{~cm}^{3}$ ), deeming any registration error margin below that distance sufficient. However, it has been reported that around a quarter of $\mathrm{PCa}$ lesions are heterogeneous as to their Gleason Score [60], suggesting that sub-lesion accuracy is important to localize the high-grade PCa core. Fortunately, in $75 \%$ of the cases, the highest Gleason Score is found in the middle of the lesion [60]. In general, high-grade hotspots of heterogeneous significant tumours are considered to be $0.3 \mathrm{~cm}^{3}$ in median volume [61] and, therefore, we should actually aim for an error under $4.1 \mathrm{~mm}$. 
Table 2 List of registration algorithms used in the prostate

\begin{tabular}{|c|c|c|c|c|c|c|c|c|c|}
\hline \multirow{2}{*}{\multicolumn{2}{|c|}{$\frac{\text { Source }}{\text { Ref. Author, year }}$}} & \multicolumn{3}{|l|}{ Registration method } & \multicolumn{5}{|l|}{ Verification } \\
\hline & & \multirow{2}{*}{$\begin{array}{l}\text { Guidance }^{\mathrm{a}} \\
\begin{array}{l}\text { Landmark-based: auto- } \\
\text { matic }\end{array}\end{array}$} & \multirow{2}{*}{$\begin{array}{l}\text { Warping }^{\mathrm{b}} \\
\text { TPS }\end{array}$} & \multirow{2}{*}{$\begin{array}{l}\text { Ex Vivo Scan } \\
\text { No }\end{array}$} & \multirow{2}{*}{$\begin{array}{l}\text { Method } \\
\text { Manual landmarks }\end{array}$} & \multirow{2}{*}{$\begin{array}{l}\text { Modality } \\
\text { MRI }\end{array}$} & \multirow{2}{*}{$\frac{2 \mathrm{D} / 3 \mathrm{D}}{3 \mathrm{D}}$} & \multirow{2}{*}{$\frac{\#^{c}}{5}$} & \multirow{2}{*}{$\frac{\mathrm{TRE}^{\mathrm{d}}(\mathrm{mm})}{0.82}$} \\
\hline [78] & Zhan, 2007 & & & & & & & & \\
\hline [28] & Ou, 2009 & $\begin{array}{l}\text { Landmark-based: auto- } \\
\text { matic }\end{array}$ & TPS & No & Manual landmarks & MRI & $3 \mathrm{D}$ & 5 & 0.79 \\
\hline [34] & Gibson, 2012 & $\begin{array}{l}\text { Landmark-based: ex vivo } \\
\text { markers }\end{array}$ & AT & Yes & $\begin{array}{l}\text { Manual ex vivo MRI } \\
\text { landmarks }\end{array}$ & MRI & $3 \mathrm{D}$ & 9 & 0.71 \\
\hline [36] & Orczyk, 2012 & Landmark-based: manual & AT & Yes & Manual landmarks & MRI & 3D & 3 & 1.59 \\
\hline [26] & Ward, 2012 & Landmark-based: manual & TPS & Yes & Manual landmarks & MRI & $2 \mathrm{D}$ & 13 & 1.1 \\
\hline [38] & Orczyk, 2013 & Landmark-based: manual & AT & No & Manual landmarks & MRI & $3 \mathrm{D}$ & 3 & 1.6 \\
\hline [46] & Commandeur, 2015 & $\begin{array}{l}\text { Landmark-based: manual } \\
\text { (contours) }\end{array}$ & BSp & No & Manual landmarks & MRI & $2 \mathrm{D}$ & 3 & 4.9 \\
\hline [13] & Schalk, 2016 & $\begin{array}{l}\text { Landmark-based: manual } \\
\text { (contours) }\end{array}$ & NN & No & $\begin{array}{l}\text { Manual (PZ-TZ) land- } \\
\text { marks }\end{array}$ & US & $3 \mathrm{D}$ & 7 & 2.1 \\
\hline [35] & Nir, 2014 & $\begin{array}{l}\text { Intensity- and landmark- } \\
\text { based }\end{array}$ & AT & Yes & Manual landmarks & MRI/US & $3 \mathrm{D}$ & 10 & 3.8 \\
\hline [37] & Porter, 2001 & $\begin{array}{l}\text { Intensity-based: cor- } \\
\text { relation }\end{array}$ & AT & Yes & Urethra & US & $3 \mathrm{D}$ & 3 & 2.4 \\
\hline [78] & Zhan, 2007 & $\begin{array}{l}\text { Intensity-based: mutual } \\
\text { information }\end{array}$ & TPS & No & Manual landmarks & MRI & $3 \mathrm{D}$ & 5 & 1.5 \\
\hline [43] & Jo, 2008 & $\begin{array}{l}\text { Intensity-based: cor- } \\
\text { relation }\end{array}$ & TPS & No & $\begin{array}{l}\text { Root-mean-square } \\
\text { manual landmarks }\end{array}$ & MRI & $2 \mathrm{D}$ & 4 & 1.5 \\
\hline [12] & Park, 2008 & $\begin{array}{l}\text { Intensity-based: mutual } \\
\text { information }\end{array}$ & TPS [79] & Yes & Medial-axes tumour & MRI/PET & $3 \mathrm{D}$ & 2 & 3.0 \\
\hline [80] & Groenendaal, 2010 & $\begin{array}{l}\text { Intensity-based: cor- } \\
\text { relation }\end{array}$ & BSp [81] & No & $\begin{array}{l}\text { Manual (contour) land- } \\
\text { marks }\end{array}$ & MRI & $3 \mathrm{D}$ & 5 & 2.2 \\
\hline [47] & Mazaheri, 2010 & $\begin{array}{l}\text { Intensity-based: binary } \\
\text { similarity }\end{array}$ & FFD-BSp [82] & No & Surface overlap & MRI & $2 \mathrm{D}$ & 24 & - \\
\hline [83] & Chappelow, 2011 & $\begin{array}{l}\text { Intensity-based: mutual } \\
\text { information }\end{array}$ & FFD-BSp [82] & No & Image similarity & MRI & $2 \mathrm{D}$ & 25 & - \\
\hline [84] & Patel, 2011 & $\begin{array}{l}\text { Intensity-based: spatially } \\
\text { weighted mutual } \\
\text { information }\end{array}$ & FFD-BSp [82] & No & $\begin{array}{l}\text { Manual (contour) land- } \\
\text { marks }\end{array}$ & MRI & $2 \mathrm{D}$ & 2 & 1.65 \\
\hline [38] & Orczyk, 2013 & $\begin{array}{l}\text { Intensity-based: mutual } \\
\text { information }\end{array}$ & AT & No & 3D volume overlap & MRI & 3D & 3 & - \\
\hline [44] & Kalavagunta, 2015 & $\begin{array}{l}\text { Intensity-based: ternary } \\
\text { similarity }\end{array}$ & AT & No & Manual landmarks & MRI & $2 \mathrm{D}$ & 35 & 1.54 \\
\hline [18] & Reynolds, 2015 & $\begin{array}{l}\text { Intensity-based: normal- } \\
\text { ized mutual informa- } \\
\text { tion }\end{array}$ & FFD-BSp [82] & No & Manual landmarks & MRI & $3 \mathrm{D}$ & 6 & 3.1 \\
\hline [45] & Guzman, 2016 & $\begin{array}{l}\text { Intensity-based: mutual } \\
\text { information }\end{array}$ & $\mathrm{BSp}[81]$ & No & Manual landmarks & MRI & $2 \mathrm{D}$ & 5 & 3.1 \\
\hline [50] & Shah, 2009 & Mould-based & - & - & Visual inspection & MRI & - & - & - \\
\hline [51] & Trivedi, 2012 & Mould-based & - & - & visual inspection & MRI & - & 1 & - \\
\hline [52] & Priester, 2014 & Mould-based & - & - & Visual inspection & MRI & - & 1 & - \\
\hline [55] & Starobinets, 2014 & Mould-based & - & - & Manual landmarks & MRI & - & 10 & 1.9 \\
\hline [53] & Elen, 2016 & Mould-based & - & - & $\begin{array}{l}\text { Manual ex vivo MRI } \\
\text { landmarks }\end{array}$ & MRI & - & $2^{\mathrm{e}}$ & 0.92 \\
\hline
\end{tabular}

${ }^{a}$ Most algorithms use a multi-step approach, usually starting with coarse rigid registration; only the last, most sophisticated registration step is mentioned

${ }^{\mathrm{b}} A T$ affine transformation, TPS thin-plate spline, ( $F F D$ )- $B S p$ (free form deformation)-basis-spline, $N N$ natural neighbour

${ }^{\mathrm{c}}$ \# Number of prostates for the verification of the performance

${ }^{\mathrm{d}}$ TRE target registration error

${ }^{\mathrm{e}}$ Only two of the six prostates were used for verification 
Fig. 3 Schematic of an example registration framework for the correlation of the US image with histopathology; (1) 3D reconstruction of the ex vivo radical prostatectomy specimen and in vivo gland (2) registration between in vivo and ex vivo model; (3) correlation of the pathology data and the contrast-enhanced recording; (4) pixel-wise superposition of the histopathologic data

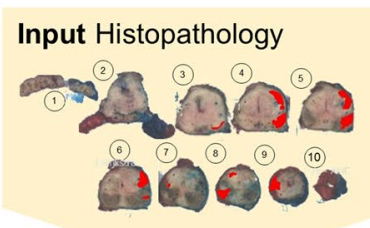

Step 1A 3D Reconstruction

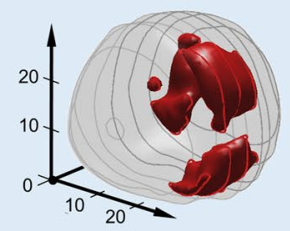

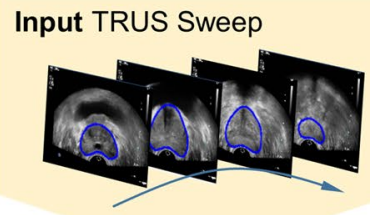

Step 1B 3D Reconstruction

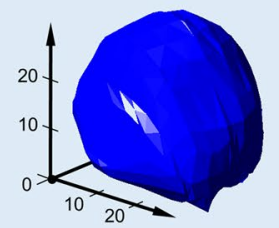

Step 2 Registration of 3D Histopathology to 3D US model
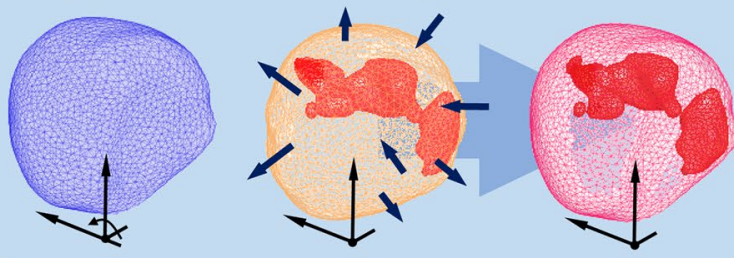

Step 3 Correlation from US Sweep to Contrast Image
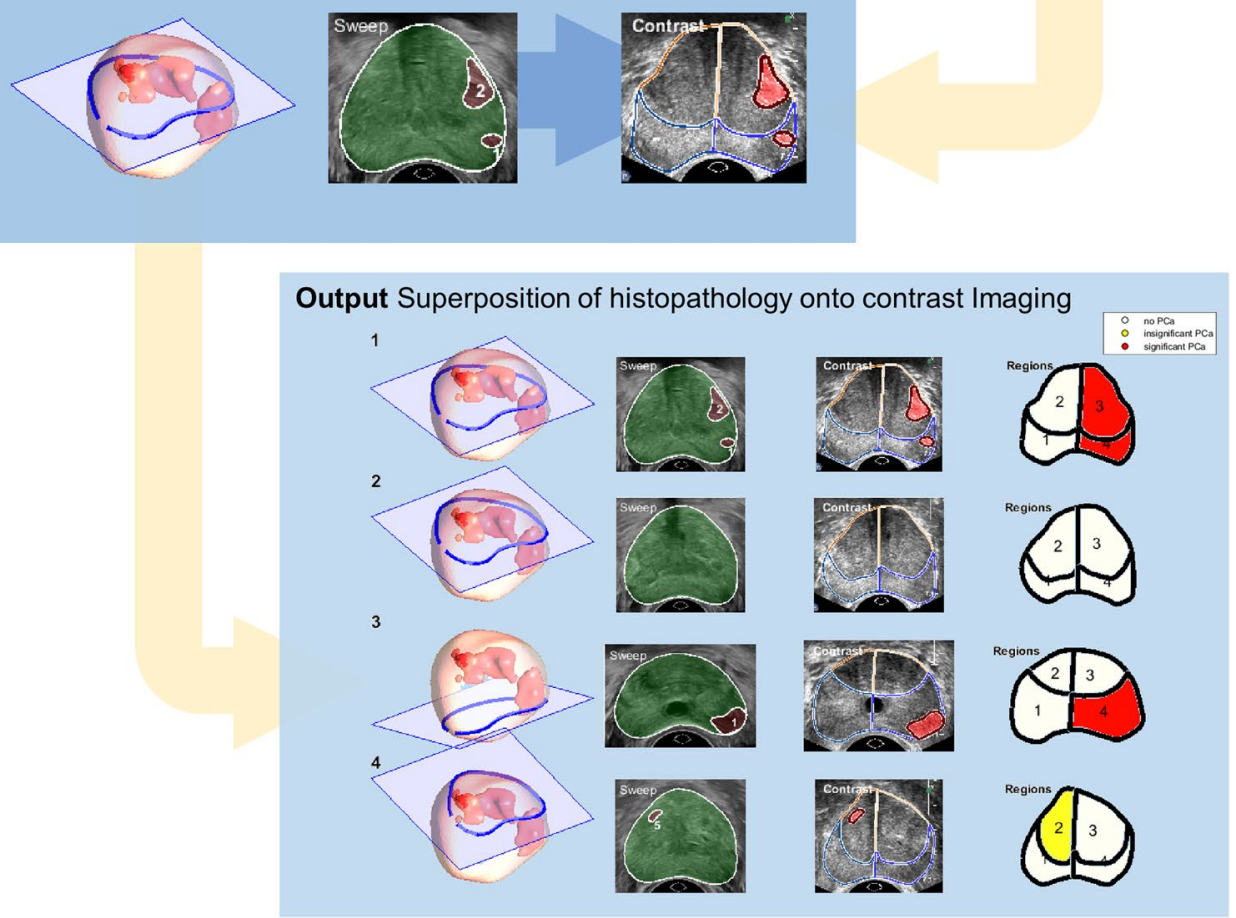

Prostate registration algorithms also play a vital role in fusion technology, in which the registration takes place between two imaging modalities [62]. Fusion generally finds its application in TRUS-guided biopsy procedures targeting suspicious areas found by another modality, in treatment planning for radiotherapy, or in the monitoring of a developing lesion over several sessions. For these purposes, respectively, recent literature features a wide range of variations of inter-modality fusion (e.g. PET-US [63],
MRI-US [64], MRI-SPECT [65], and MRI-CT [66]) and intra-modality fusion techniques (e.g. US-US [67], CT-CT [68], and MRI-MRI [69]). Although fundamentally these algorithms can be extended for registration of imaging and histology, they are usually optimized for in vivo registration and do not have to cope with the large deformations typical for ex vivo specimens.

Clearly, registration is not the only source of inaccuracy in PCa validation. The quality of the imaging, segmentation, 
or (automatic) landmark detection affect the result as well. Prostate motion could also hinder the registration procedure, but, in contrast to MRI and PET, US acquisitions are generally sufficiently fast to avoid this. Displacements due to respiration, however, have been measured in the order of several millimetres and the use of transrectal equipment is known to stimulate muscular contractions [70]. This might severely affect ultrasound modalities with a longer acquisition time.

\section{Conclusion}

It is important to be aware of the limitations and accuracy of registration techniques in PCa imaging. Unfortunately, implementation of full-registration procedures is still scarce in current $\mathrm{PCa}$ imaging studies. With the shift from $\mathrm{PCa}$ detection to PCa localization [71], however, such validation will be indispensable to study the imaging performance. In this review, the wide range of validation strategies has been discussed in the light of ultrasonic imaging. We also provided guidelines for registration and an example of a rigorous pixel-to-pixel matching procedure.

Funding This study has received funding from the Dutch Cancer Society (\#UVA2013-5941), a European Research Council Starting Grant (\#280209), a research grant from Astellas Pharma Netherlands B.V., and was performed within the framework of the IMPULS2-program within the Eindhoven University of Technology in collaboration with Philips.

\section{Compliance with ethical standards}

Conflict of Interest Rogier Wildeboer declares relationships with Philips.

Ethical approval All procedures performed in studies involving human participants were in accordance with the ethical standards of the institutional and/or national research committee and with the 1964 Helsinki declaration and its later amendments or comparable ethical standards.

Informed consent Informed consent was obtained from all individual participants included in the study.

Open Access This article is distributed under the terms of the Creative Commons Attribution 4.0 International License (http://creativeco mmons.org/licenses/by/4.0/), which permits unrestricted use, distribution, and reproduction in any medium, provided you give appropriate credit to the original author(s) and the source, provide a link to the Creative Commons license, and indicate if changes were made.

\section{References}

1. American Cancer Society (2017) Cancer facts \& figures 2017. American Cancer Society, Atlanta
2. Mottet N, Bellmunt J, Bolla M et al (2017) EAU-ESTRO-SIOG Guidelines on prostate cancer. Part 1: screening, diagnosis, and local treatment with curative intent. Eur Urol 71:618-629

3. Graif T, Loeb S, Roehl KA, Gashti SN, Griffin C, Yu X, Catalona WJ (2007) Under diagnosis and over diagnosis of prostate cancer. J Urol 178:88-92

4. Loeb S, Vellekoop A, Ahmed HU, Catto J, Emberton M, Nam R, Rosario DJ, Scattoni V, Lotan Y (2013) Systematic review of complications of prostate biopsy. Eur Urol 64:876-892

5. Barret E, Durand M (2015) Technical aspects of focal therapy in localized prostate cancer. Tech Asp Focal Ther Localized Prostate Cancer. https://doi.org/10.1007/978-2-8178-0484-2

6. Fütterer JJ, Briganti A, De Visschere P, Emberton M, Giannarini G, Kirkham A, Taneja SS, Thoeny H, Villeirs G, Villers A (2015) Can clinically significant prostate cancer be detected with multiparametric magnetic resonance imaging? A systematic review of the literature. Eur Urol 68:1045-1053

7. de Rooij M, Hamoen EHJ, Fütterer JJ, Barentsz JO, Rovers MM (2014) Accuracy of multiparametric MRI for prostate cancer detection: a meta-analysis. Am J Roentgenol 202:343-351

8. Li Y, Tang J, Fei X, Gao Y (2013) Diagnostic performance of contrast enhanced ultrasound in patients with prostate cancer: a meta-analysis. Acad Radiol 20:156-164

9. Kuru TH, Fütterer JJ, Schiffmann J, Porres D, Salomon G, Rastinehad AR (2015) Transrectal ultrasound (US), contrast-enhanced US, real-time elastography, histoscanning, magnetic resonance imaging (MRI), and MRI-US fusion biopsy in the diagnosis of prostate cancer. Eur Urol Focus 1:117-126

10. Umbehr MH, Müntener M, Hany T, Sulser T, Bachmann LM (2013) The role of 11C-choline and 18F-fluorocholine positron emission tomography (PET) and PET/CT in prostate cancer: a systematic review and meta-analysis. Eur Urol 64:106-117

11. Xiao G, Bloch BN, Chappelow J, Genega EM, Rofsky NM, Lenkinski RE, Tomaszewski J, Feldman MD, Rosen M, Madabhushi A (2011) Determining histology-MRI slice correspondences for defining MRI-based disease signatures of prostate cancer. Comput Med Imaging Graph 35:568-578

12. Park H, Piert MR, Khan A, Shah R, Hussain H, Siddiqui J, Chenevert TL, Meyer CR (2008) Registration methodology for histological sections and in vivo imaging of human prostate. Acad Radiol 15:1027-1039

13. Schalk SG, Postema A, Saidov TA, Demi L, Smeenge M, de la Rosette JJMCH, Wijkstra H, Mischi M (2016) 3D surface-based registration of ultrasound and histology in prostate cancer imaging. Comput Med Imaging Graph 47:29-39

14. Cool D, Downey D, Izawa J, Chin J, Fenster A (2006) 3D prostate model formation from non-parallel 2D ultrasound biopsy images. Med Image Anal 10:875-887

15. Montironi R, van der Kwast T, Boccon-Gibod L, Bono AV, Boccon-Gibod L (2003) Handling and pathology reporting of radical prostatectomy specimens. Eur Urol 44:626-636

16. Samaratunga H, Montironi R, True L, Epstein JI, Griffiths DF, Humphrey PA, Van Der Kwast T, Wheeler TM, Srigley JR, Delahunt B (2011) International society of urological pathology (ISUP) consensus conference on handling and staging of radical prostatectomy specimens. Working group 1: specimen handling. Mod Pathol 24:6

17. Salarian M, Shahedi M, Gibson E, Gaed M, Gómez JA, Moussa M, Bauman GS, Ward AD (2013) Toward quantitative digital histopathology for prostate cancer: comparison of inter-slide interpolation methods for tumour measurement. In: Proceedings of SPIE 8676, medical imaging 2013: digital pathology, 86760F. https:// doi.org/10.1117/12.2007103

18. Reynolds HM, Williams S, Zhang A et al (2015) Development of a registration framework to validate MRI with histology for prostate focal therapy. Med Phys 42:7078-7089 
19. Meyer C, Ma B, Kunju LP, Davenport M, Piert M (2013) Challenges in accurate registration of 3D medical imaging and histopathology in primary prostate cancer. Eur J Nucl Med Mol Imaging 40:72-78

20. Huang Q, Zeng Z (2017) A Review on real-time 3D ultrasound imaging technology. Biomed Res, Int

21. Gibson E, Gaed M, Gómez JA, Moussa M, Pautler S, Chin JL, Crukley C, Bauman GS, Fenster A, Ward AD (2013) 3D prostate histology image reconstruction: quantifying the impact of tissue deformation and histology section location. J Pathol Inform. 4:31. http://www.jpathinformatics.org/text.asp?2013/4/1/31/120874

22. Egevad L, Algaba F, Berney DM, Boccon-Gibod L, Griffiths DF, Lopez-Beltran A, Mikuz G, Varma M, Montironi R (2008) Handling and reporting of radical prostatectomy specimens in Europe: a web-based survey by the European network of uropathology (ENUP). Histopathology 53:333-339

23. Yamamoto H, Nir D, Vyas L, Chang RT, Popert R, Cahill D, Challacombe B, Dasgupta P, Chandra A (2014) A Workflow to Improve the Alignment of prostate Imaging with whole-mount histopathology. Acad Radiol 21:1009-1019

24. Chen LH, Ho H, Lazaro R, Thng CH, Yuen J, Ng WS, Cheng C (2010) Optimum slicing of radical prostatectomy specimens for correlation between histopathology and medical images. Int J Comput Assist Radiol Surg 5:471-487

25. Gibson E, Gómez JA, Moussa M, Crukley C, Bauman G, Fenster A, Ward AD (2012) 3D reconstruction of prostate histology based on quantified tissue cutting and deformation parameters. In: Proceedings of SPIE 8317, Medical imaging 2012: biomedical applications in molecular, structural, and functional imaging, 83170N. https://doi.org/10.1117/12.912363

26. Ward AD, Crukley C, McKenzie CA, Montreuil J, Gibson E, Romagnoli C, Gomez JA, Moussa M, Chin J, Bauman G (2012) Prostate: registration of digital histopathologic images to in vivo MR images acquired by using endorectal receive coil. Radiology 263:856-864

27. Hughes C, Rouviere O, Mege-Lechevallier F, Souchon R, Prost R (2013) Robust alignment of prostate histology slices with quantified accuracy. Biomed Eng IEEE Trans 60:281-291

28. Ou Y, Shen D, Feldman M, Tomaszewski J, Davatzikos C (2009) Non-rigid registration between histological and MR images of the prostate: a joint segmentation and registration framework. In: 2009 IEEE computer society conference on computer vision and pattern recognition workshops, pp 125-132. https://doi. org/10.1109/CVPRW.2009.5204347

29. Taylor LS, Porter BC, Nadasdy G, di Sant'Agnese PA, Pasternack D, Wu Z, Baggs RB, Rubens DJ, Parker KJ (2004) Threedimensional registration of prostate images from histology and ultrasound. Ultrasound Med Biol 30:161-168

30. Rojas KD, Montero ML, Yao J et al (2015) Methodology to study the three-dimensional spatial distribution of prostate cancer and their dependence on clinical parameters. J Med Imaging 2:37502

31. Malone SC, Haridass A, Nyiri B, Croke J, Malone C, Breau RH, Morash C, Avruch L, Daneshmand M, Malone K (2014) Creation of 3-dimensional prostate cancer maps: methodology and clinical and research implications. Arch Pathol Lab Med 138:803-808

32. Haffner J, Potiron E, Bouyé S, Puech P, Leroy X, Lemaitre L, Villers A (2009) Peripheral zone prostate cancers: location and intraprostatic patterns of spread at histopathology. Prostate 69:276-282

33. Wildeboer RR, Schalk SG, Demi L, Wijkstra H, Mischi M (2017) Three-dimensional histopathological reconstruction as a reliable ground truth for prostate cancer studies. Biomed Phys Eng Express 3:35014

34. Gibson E, Crukley C, Gaed M, Gómez JA, Moussa M, Chin JL, Bauman GS, Fenster A, Ward AD (2012) Registration of prostate histology images to ex vivo MR images via strand-shaped fiducials. J Magn Reson Imaging 36:1402-1412

35. Nir G, Sahebjavaher RS, Kozlowski P, Chang SD, Jones EC, Goldenberg SL, Salcudean SE (2014) Registration of wholemount histology and volumetric imaging of the prostate using particle filtering. Med Imaging, IEEE Trans 33:1601-1613

36. Orczyk C, Mikheev A, Rosenkrantz AB, Melamed J, Taneja SS, Rusinek H (2012) Imaging of prostate cancer: a platform for 3D co-registration of in vivo MRI ex vivo MRI and pathology. Proc SPIE Int Soc Opt Eng 8316:83162M

37. Porter BC, Taylor L, Baggs R, di Sant'Agnese A, Nadasdy G, Pasternack D, Rubens DJ, Parker KJ (2001) Histology and ultrasound fusion of excised prostate tissue using surface registration. IEEE Ultrason Symp Proc An Int Symp (Cat No01CH37263) 2:1473-1476 (Vol.2)

38. Orczyk C, Rusinek H, Rosenkrantz AB, Mikheev A, Deng F-M, Melamed J, Taneja SS (2013) Preliminary experience with a novel method of three-dimensional co-registration of prostate cancer digital histology and in vivo multiparametric MRI. Clin Radiol 68:e652-e658

39. Orczyk C, Taneja SS, Rusinek H, Rosenkrantz AB (2014) Assessment of change in prostate volume and shape following surgical resection through co-registration of in vivo MRI and fresh specimen ex vivo MRI. Clin Radiol 69:e398-e403

40. Jonmarker S, Valdman A, Lindberg A, Hellström M, Egevad L (2006) Tissue shrinkage after fixation with formalin injection of prostatectomy specimens. Virchows Arch 449:297-301

41. Zhai L, Madden J, Foo W-C, Palmeri ML, Mouraviev V, Polascik TJ, Nightingale KR (2010) Acoustic Radiation Force Impulse Imaging of Human Prostates Ex Vivo. Ultrasound Med Biol 36:576-588

42. Souchon R, Hervieu V, Gelet A, Ophir J, Chapelon JY (2003) Human prostate elastography: in vitro study. IEEE Symp Ultrason 2:1251-1253 (Vol.2)

43. Jo HH, Jung J, Jang Y, Hong H, Lee HJ (2008) Histopathology and MR image fusion of the prostate. In: Proceedings of SPIE 6914, medical imaging 2008: image processing, p 691430. https://doi. org $/ 10.1117 / 12.771380$

44. Kalavagunta C, Zhou X, Schmechel SC, Metzger GJ (2015) Registration of in vivo prostate MRI and pseudo-whole mount histology using local affine transformations guided by internal structures (LATIS). J Magn Reson Imaging 41:1104-1114

45. Guzmán L, Commandeur F, Acosta O, Simon A, Fautrel A, Rioux-Leclercq N, Romero E, Mathieu R, Crevoisier R de (2016) Slice correspondence estimation using SURF descriptors and context-based search for prostate whole-mount histology MRI registration. In: 38th annual international conference of the IEEE engineering in medicine and biology society (EMBC), pp 1163-1166. https://doi.org/10.1109/EMBC.2016.7590911

46. Commandeur F, Acosta O, Simon A, Mathieu R, Fautrel A, Gnep K, Haigron P, de Crevoisier R (2015) Prostate wholemount histology reconstruction and registration to MRI for correlating in vivo observations with biological findings. In: Engineering in medicine and biology society (EMBC), 37th annualinternational conference of the IEEE, pp 2399-2402. https://doi.org/10.1109/EMBC.2015.7318877

47. Mazaheri Y, Bokacheva L, Kroon D-J, Akin O, Hricak H, Chamudot D, Fine S, Koutcher JA (2010) Semi-automatic deformable registration of prostate MR images to pathological slices. J Magn Reson Imaging 32:1149-1157

48. Kybic J, Unser M (2003) Fast parametric elastic image registration. IEEE Trans Image Process 12:1427-1442

49. Bookstein FL (1989) Principal warps: thin-plate splines and the decomposition of deformations. IEEE Trans Pattern Anal Mach Intell 11:567-585 
50. Shah V, Pohida T, Turkbey B, Mani H, Merino M, Pinto PA, Choyke P, Bernardo M (2009) A method for correlating in vivo prostate magnetic resonance imaging and histopathology using individualized magnetic resonance-based molds. Rev Sci Instrum 80:104301

51. Trivedi H, Turkbey B, Rastinehad AR et al (2012) Use of patient-specific MRI-based prostate mold for validation of multiparametric MRI in localization of prostate cancer. Urology 79:233-239

52. Priester A, Natarajan S, Le JD, Garritano J, Radosavcev B, Grundfest W, Margolis DJA, Marks LS, Huang J (2014) A system for evaluating magnetic resonance imaging of prostate cancer using patient-specific 3D printed molds. Am J Clin Exp Urol 2:127

53. Elen A, Isebaert S, De Keyzer F et al. (2016) Validation of an improved patient-specific mold design for registration of In-vivo MRI and histology of the prostate. In: Shekhar R et al (eds) Clinical image-based procedures. Translational research in medical imaging. CLIP 2016. Lecture notes in computer science, vol 9958. Springer, Cham. https://doi.org/10.1007/978-3-319-46472-5_5

54. Bourne RM, Bailey C, Johnston EW et al (2017) Apparatus for histological validation of in vivo and ex vivo magnetic resonance imaging of the human prostate. Front Oncol 7:47

55. Starobinets O, Guo R, Simko JP, Kuchinsky K, Kurhanewicz J, Carroll PR, Greene KL, Noworolski SM (2014) Semiautomatic registration of digital histopathology images to in vivo MR images in molded and unmolded prostates. J Magn Reson Imaging 39:1223-1229

56. Oliveira FPM, Tavares JMRS (2014) Medical image registration: a review. Comput Methods Biomech Biomed Engin 17:73-93

57. Sauvain JL, Sauvain E, Papavero R, Louis D, Rohmer P (2016) Limiting overdiagnosis of low-risk prostate cancer through an evaluation of the predictive value of transrectal and power doppler ultrasonography. J Ultrasound 19:275-280

58. Barr RG, Cosgrove D, Brock M, Cantisani V, Correas JM, Postema AW, Salomon G, Tsutsumi M, Xu H-X, Dietrich CF (2017) WFUMB guidelines and recommendations on the clinical use of ultrasound elastography: part 5. Prostate. Ultrasound Med Biol 43:27-48

59. Cantisani V, Bertolotto M, Weskott HP et al (2015) Growing indications for CEUS: the kidney, testis, lymph nodes, thyroid, prostate, and small bowel. Eur J Radiol 84:1675-1684

60. El-Shater Bosaily A, Valerio M, Hu Y et al (2016) The concordance between the volume hotspot and the grade hotspot: a 3-D reconstructive model using the pathology outputs from the PROMIS trial. Prostate Cancer Prostatic Dis 19:322

61. Van de Ven WJM, Litjens GJS, Barentsz JO, Hambrock T, Huisman HJ (2011) Required accuracy of MR-US registration for prostate biopsies BT-prostate cancer imaging. image analysis and image-guided interventions: international workshop, held in conjunction with MICCAI 2011, Toronto, Canada, September 22, 2011. Proceedings. In: Madabhushi A, Dowling J, Huisman H, Barratt D (eds). Springer Berlin Heidelberg, Berlin, Heidelberg, pp 92-99

62. Cornud F, Brolis L, Delongchamps NB, Portalez D, Malavaud B, Renard-Penna R, Mozer P (2013) TRUS-MRI image registration: a paradigm shift in the diagnosis of significant prostate cancer. Abdom Imaging 38:1447-1463

63. Yang X, Akbari H, Halig L, Fei B (2011) 3D non-rigid registration using surface and local salient features for transrectal ultrasound image-guided prostate biopsy. In: Proceedings of SPIE 7964, medical imaging 2011: visualization, image-guided procedures, and modeling, 79642V. https://doi.org/10.1117/12.878153

64. Onofrey JA, Staib LH, Sarkar S, Venkataraman R, Nawaf CB, Sprenkle PC, Papademetris X (2017) Learning non-rigid deformations for robust, constrained point-based registration in image-guided MR-TRUS prostate intervention. Med Image Anal 39:29-43

65. Fei B, Duerk JL, Wilson DL (2002) Automatic 3D registration for interventional MRI-guided treatment of prostate cancer. Comput Aided Surg 7:257-267

66. Yang X, Jani AB, Rossi PJ, Mao H, Curran WJ, Liu T (2016) A MRI-CT prostate registration using sparse representation technique. In: Proceedings of SPIE 9786, medical imaging 2016: image-guided procedures, robotic interventions, and modeling, p 978627. https://doi.org/10.1117/12.2216430

67. Guo Y, Werahera PN, Narayanan R, Li L, Kumar D, Crawford ED, Suri JS (2009) Image registration accuracy of a 3-dimensional transrectal ultrasound-guided prostate biopsy system. J Ultrasound Med 28:1561-1568

68. Lu C, Chelikani S, Papademetris X, Staib L, Duncan J (2010) Constrained non-rigid registration using lagrange multipliers for application in prostate radiotherapy. IEEE Comput Soc Conf Comput Vis Pattern Recognit Work 2010:133-138

69. Marami B, Sirouspour S, Ghoul S, Cepek J, Davidson SRH, Capson DW, Trachtenberg J, Fenster A (2015) Elastic registration of prostate MR images based on estimation of deformation states. Med Image Anal 21:87-103

70. Dinkel J, Thieke C, Plathow C, Zamecnik P, Prüm H, Huber PE, Kauczor H-U, Schlemmer H-P, Zechmann CM (2011) Respiratory-induced prostate motion. Strahlentherapie und Onkol 187:426-432

71. Turkbey B, Choyke PL (2014) Decade in review-imaging: a decade in image-guided prostate biopsy. Nat Rev Urol 11:611-612

72. Raya SP, Udupa JK (1990) Shape-based interpolation of multidimensional objects. IEEE Trans Med Imaging 9:32-42

73. Hughes C, Rouviere O, Mege-Lechevallier F, Souchon R, Prost R (2012) A novel method for 3D prostate MR-histology registration using anatomical landmarks. In: Proceedings of the 20th European signal processing conference (EUSIPCO), pp 2591-2594

74. Werahera PN, Miller GJ, Taylor GD, Brubaker T, Daneshgari F, Crawford ED (1995) A 3-D reconstruction algorithm for interpolation and extrapolation of planar cross sectional data. IEEE Trans Med Imaging 14:765-771

75. Xuan J, Sesterhenn IA, Hayes WS, Wang YJ, Adali T, Yagi Y, Freedman MT, Mun SK (1997) Surface reconstruction and visualization of the surgical prostate model. In: Proceedings of SPIE 3031, medical imaging 1997: image display. https://doi. org/10.1117/12.273939

76. Tutar IB, Pathak SD, Kim Y (2004) 3D prostate shape modeling from sparsely acquired 2D images using deformable models. In: Proceedings of SPIE 5367, medical imaging 2004: visualization, image-guided procedures, and display. https://doi. org/10.1117/12.536809

77. Hibbard LS (2012) Anatomy structure creation and editing using 3D implicit surfaces. Med Phys 39:2649-2658

78. Zhan Y, Ou Y, Feldman M, Tomaszeweski J, Davatzikos C, Shen D (2007) Registering histologic and MR images of prostate for image-based cancer detection. Acad Radiol 14:1367-1381

79. Meyer CR, Boes JL, Kim B, Bland PH, Zasadny KR, Kison PV, Koral K, Frey KA, Wahl RL (1997) Demonstration of accuracy and clinical versatility of mutual information for automatic multimodality image fusion using affine and thin-plate spline warped geometric deformations. Med Image Anal 1:195-206

80. Groenendaal G, Moman MR, Korporaal JG, van Diest PJ, van Vulpen M, Philippens MEP, van der Heide UA (2010) Validation of functional imaging with pathology for tumor delineation in the prostate. Radiother Oncol 94:145-150

81. Klein S, Staring M, Murphy K, Viergever MA, Pluim JPW (2010) Elastix: a toolbox for intensity-based medical image registration. IEEE Trans Med Imaging 29:196-205 
82. Rueckert D, Sonoda LI, Hayes C, Hill DLG, Leach MO, Hawkes DJ (1999) Nonrigid registration using free-form deformations: application to breast MR images. IEEE Trans Med Imaging $18: 712-721$

83. Chappelow J, Bloch BN, Rofsky N, Genega E, Lenkinski R, DeWolf W, Madabhushi A (2011) Elastic registration of multimodal prostate MRI and histology via multiattribute combined mutual information. Med Phys 38:2005-2018
84. Patel P, Chappelow J, Tomaszewski J, Feldman MD, Rosen M, Shih N, Madabhushi A (2011) Spatially weighted mutual information (SWMI) for registration of digitally reconstructed ex vivo whole mount histology and in vivo prostate MRI. Annu Int Conf IEEE Eng Med Biol Soc 2011:6269-6272 